\title{
Airway Resistance and Lung Volume in the Newborn Infant
}

\author{
Carl F. Doershuk ${ }^{[17]}$ and LeRoy W. Matthews \\ Department of Pediatrics, Case Western Reserve University School of Medicine, \\ and the Babies' and Children's Division of University Hospitals, Cleveland, Ohio, USA
}

\begin{abstract}
Extract
The total body plethysmograph method of DuBors et al. [7] for measurement of lung volume and airway resistance was adapted to the study of newborn infants. A Rendell-Baker mask directly controlled by the operator proved by trial and error to minimize the chances of pressure leaks and undesirable pressure on the nose and allowed the mandible to be pulled forward to minimize pharyngeal obstruction. Use of an oscilloscope for direct visualization of flow and pressure tracings was essential in order to detect immediately pressure leaks, artifacts, and abnormal patterns during measurements of both lung volume and airway resistance.

Interpretation of the measurements of airway resistance and of the relation of conductance to lung volume over a wide range of age and lung volumes requires that the flow rates at which measurements are made be recorded, along with lung volumes.

In 51 newborn infants, an airway resistance value of $19.2 \pm 5.6 \mathrm{~cm} \mathrm{H}_{2} \mathrm{O} / 1 / \mathrm{s}$ was observed. Thoracic gas volume at functional residual capacity was $89.9 \pm 15.5 \mathrm{ml}$. The resulting mean value for conductance (reciprocal of airway resistance), $0.052 \mathrm{l} / \mathrm{s} / \mathrm{cm} \mathrm{H}_{2} \mathrm{O}$, fell above the calculated regressions of conductance versus lung volume determined by BRISCOE and DuBoIs [3], who used data obtained from older children and adults. Direct conıparison is limited since airway resistance in the older subjects was usually obtained using panting flow rates of $0.5 \mathrm{l} / \mathrm{s}$, while the infants in this study had flow rates of approximately $0.1 \mathrm{l} / \mathrm{s}$ at the time airway resistance was measured.
\end{abstract}

\section{Speculation}

Confirmation of the presence of the major expiratory flow-limiting segment in the nasal airway of newborn and small infants is needed. This location suggests a physiologic means for slowing expiratory flow and thus maintaining expiratory intraluminal pressure in the tracheobronchial tree, which might protect the compliant trachea and major bronchi from compression by positive intrapleural pressure in obstructive pulmonary disease. It is possible that there is an airflow-lung volume-airway resistance relation throughout life; however, a wide range of control data will be required to establish such a relation. 


\section{Introduction}

Measurements of airway resistance and associated lung volume in adults and older children have been available for some time. There is less information about these measurements, however, in infants and in subjects under four years of age. Cook et al. [5] and SwYER et al. [13] employed an esophageal catheter and total body plethysmograph to obtain pressure-volume curves and indirectly calculated resistance in newborn infants. PoLGAR [11, 12] used a pneumotachometer, oscilloscope, and the total body plethysmograph method of Dubors et al. [7] to measure airway resistance in the newborn; he used an esophageal catheter to measure compliance. BRIScoe and DuBors [3] studied the relation of conductance (the reciprocal of airway resistance) to lung volume in healthy subjects 4 to 87 years of age. They reported a regression of conductance on lung volume throughout the range of lung volume $(0.8$ to $5 \mathrm{l}$ ) of the subjects studied. MEAD [9], however, postulated that the rate of growth and the relation of airway conductance to lung volume is not the same for all age groups.

Further study of these parameters in healthy infants and young children is essential for understanding the changing relations in the lung with growth. Establishment of age-related normal values will permit the study of obstructive pulmonary diseases prevalent in infants and young children. Most of these diseases result in an increase in lung volume, over-inflation, and/ or an increase in airway resistance. The total body plethysmograph method [7] permits measurement of both airway resistance and lung volume. This technique was modified for the study of infants and children below the age of five years. The interrelations of the data obtained on normal newborn infants are presented here.

\section{Methods}

A body plethysmograph (figs. 1 and 2) was made of one-half inch plastic, which provided ample rigidity for the box. The volume was 140 liters. One end was designed to slide open to permit placement of the infant or child supine on the bed frame. When closed, four silent-operating locks held the two sections together around an airtight, rubber seal. Two smaller plastic boxes were used together or interchangeably to decrease the volume of the chamber. A two-inch circular cuffed-opening in the side of the plethysmograph permitted entrance of the operator's hand and forearm to apply the face mask. The monocellular rubber gasket cuffing the opening was flexible enough to permit entrance of the hand and to provide an airtight
Fig. 1. Design of the total body plethysmograph. In operation, the box is closed. The opening in the side is for the operator's arm and hand. The pneumotachometer and face mask are to the left. The calibrating pump is on the right.

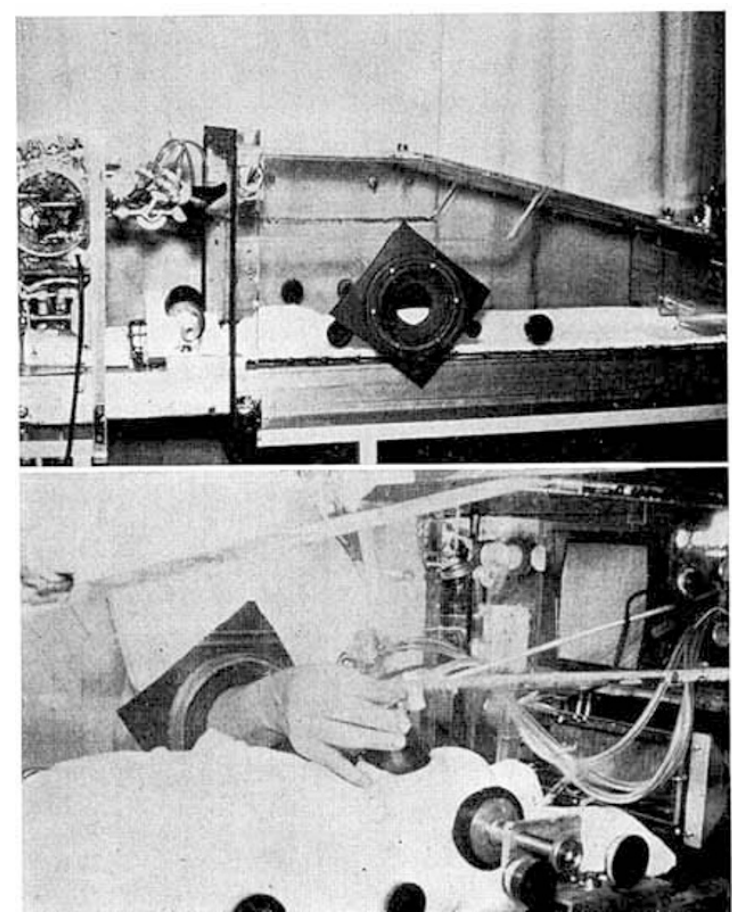

Fig.2. A close-up view showing the infant, mask, pneumotachometer tubes leading to pressure transducers outside plethysmograph, solenoid control cable, and operator's hand with rubber cuff tight around forearm.

fit around the arm, yet rigid enough to withstand the pressure changes that occurred during the procedure.

A size 0 or 1 Rendell-Baker mask was applied over the nose and closed mouth of the infant. An airtight seal was ensured by application of a light coating of vaseline on the edge of the mask. Care was necessary to avoid any pressure on the tip of the nose, since airway resistance was markedly increased by very little pressure. Attached to the mask was a $2-\mathrm{cm}$ diameter, heated, calomel wire-mesh pneumotachometer with a linear flow response of $0.3 \mathrm{l} / \mathrm{s}$. The resistance value of the pneumotachometer was very low $(0.21 / \mathrm{s})$, compared with that of airway resistance, and was subtracted from all measurements of airway resistance. The value for total airway resistance was corrected by subtracting one-half the volume of the dead space [7], 
which was assumed to be $2.3 \mathrm{ml} / \mathrm{kg}$ body weight. Two Sanborn P270 transducers were used to measure box pressure and flow changes; a Sanborn P268 transducer was used to measure airway pressure. A Sanborn Model 150 recorder and a modified Sanborn Model 769 oscilloscope were also used. The face mask was controlled by the operator at all times. A cable-release manual shutter, which could be operated from outside the plethysmograph and closed at end-tidal expiration, was positioned between the mask and the flowmeter. The volumes of dead space of the mask and airway to the shutter were approximated and subtracted from all measurements of lung volume. Changes in box pressure were calibrated by the rapid introduction and withdrawal of $30 \mathrm{ml}$ of air delivered from a calibrated pump while the infant was in the plethysmograph. The pneumotachometer was calibrated with a Brooks flowmeter, the calibration of which was verified using a Tissot spirometer.

Fifty-one normal, full-term infants were selected from the newborn nursery [14] after a feeding. None showed clinical cardiopulmonary abnormalities at the time of the study or during their hospital stay. The mean age was 3 days (range 2 hours to 11 days). They were swaddled and lightly restrained. All infants studied were quiet but not asleep. A few required a brief period of adjustment to the circumoral stimulation of the mask. Those who were obviously awake or irritable were omitted or brought back for study after another regular feeding. Parental permission by signed consent was obtained in all cases.

The lower jaw was held upward and the mouth held closed during each measurement. No difficulty was experienced in obtaining either flow or pressure measurements. Nasal obstruction or air leaks were readily detected from the oscilloscope tracing. The mask was repositioned until acceptable and reproducible tracings were observed. Ten determinations were made on each subject. Expiratory slopes at flow rates of approximately $0.1 \mathrm{l} / \mathrm{s}$ were used to measure airway resistance, and efforts were made to measure thoracic gas volume (TGV) at end-tidal expiration or functional residual capacity (FRG). No marked alteration in respiratory pattern was observed when the mask was applied; however, the $14 \mathrm{ml}$ of dead space may have caused an increase in depth of respiration and flow rate. The normal, rapid respiratory rate of the newborn infant facilitated these measurements. Conductance was calculated as the reciprocal of airway resistance. Tidal volume, respiratory rate, and inspiratory and expiratory flow rates reported on 36 of the infants were obtained from pneumotachometer tracings at the time of the study and do not represent basal levels. It is possible that these infants were somewhat stimulated by closure of the airway during the test procedure.

\section{Results}

The results are summarized in table I. Values for TGV at FRC and airway resistance were determined in 51 newborn infants. The mean weight of subjects was 4040 grams (range 2200 to 4140 ); the mean length was $49.0 \mathrm{~cm}$ (range 46 to 54). Correlation of TGV at FRC with age $(r=0.35)$ and length $(r=0.23)$ was poor over the narrow age and length ranges studied (fig. 3). The mean value for TGV was $89.9 \pm 15.5 \mathrm{ml}$ (range 62 to 131). Related to body weight, the mean value for TGV was $29 \pm 6 \mathrm{ml} / \mathrm{kg}$. Correlation of airway resistance with age $(r=0.06)$, weight $(r=-0.05)$, and length $(\mathrm{r}=0.03)$ was very poor. When airway measurements were related to the lung volumes at which they were measured, the correlation coefficient of -0.33 was comparable to that for FRC and length (fig. 4). The mean value for airway resistance was $19.2 \pm 5.6 \mathrm{~cm} \mathrm{H}_{2} \mathrm{O} / 1 / \mathrm{s}$ (range 10.3 to 40.5 ), resulting in a mean value for conductance of $0.052 \pm 0.015 \mathrm{l} / \mathrm{s} / \mathrm{cm}$ $\mathrm{H}_{2} \mathrm{O}$.

The mean respiratory rate of 36 of the infants was $67 \pm 17$ breaths per minute. The mean tidal volume of $25 \pm 4 \mathrm{ml}$ resulted in a mean minute volume of $1721 \pm 399 \mathrm{ml}$. The tidal volume per unit body weight was $8.4 \pm 1.8 \mathrm{ml} / \mathrm{kg}$, and the mean minute volume per unit body weight was $588 \pm 115 \mathrm{ml} / \mathrm{kg}$. The mean peak inspiratory flow rate of $0.09 \mathrm{l} / \mathrm{s}$ was somewhat higher than the mean peak expiratory flow rate of $0.08 \mathrm{l} / \mathrm{s}$ during tidal respiration, and is comparable to that occurring when measurements of lung volume and airway resistance were obtained and were not basal.

\section{Discussion}

The value for TGV at FRC, expressed as $\mathrm{ml} / \mathrm{kg}$ body weight for the 51 infants in this study is similar to that found by KLAUS [8] and AULD [1] and less than that measured by NeLson [10] using a similar technique.

Our results also confirm the findings of NELSON [10] and CHU [4] that the value for FRG, expressed as $\mathrm{ml} / \mathrm{kg}$ body weight, is larger in the smaller babies. The value of TGV at FRC for normal newborns, measured in the supine position, falls near the extrapolated regressions of FRG versus height determined by studying seated older children and adults (fig. 3 ) and indicates a logarithmic relation of FRC to body length throughout life.

In older subjects, airway resistance and its reciprocal, conductance, change in relation to the TGV at which these are measured. Little has been reported of this relation in infants and children. In this study, the values for airway resistance during nasal breathing are very similar to the value of $18.1 \pm 6.0 \mathrm{~cm} \mathrm{H}_{2} \mathrm{O} / \mathrm{l} / \mathrm{s}$ 
obtained in 15 infants by Polgar [11], who used a similar method, but it is less than the value of $28.5 \mathrm{~cm}$ $\mathrm{H}_{2} \mathrm{O} / 1 / \mathrm{s}$ he reported later for 14 infants [12]. The infants in the latter study had a mean lung volume of $0.07 \pm 0.0181$, a value considerably less than that of our 51 infants, and higher resistance would be expected.

In the present study, values for resistance were also lower than those obtained by Cook et al. [5], $29 \mathrm{~cm}$ $\mathrm{H}_{2} \mathrm{O} / \mathrm{l} / \mathrm{s}(\mathrm{SE} \pm 4)$ in 18 infants, or by SwYER et al. [13], $26 \mathrm{~cm} \mathrm{H} \mathrm{H}_{2} \mathrm{O} / \mathrm{1} / \mathrm{s}$ in 9 infants. These investigators used a plethysmograph and pressure-volume tracing to calculate resistance and employed a water-filled esophageal catheter connected to a pressure transducer

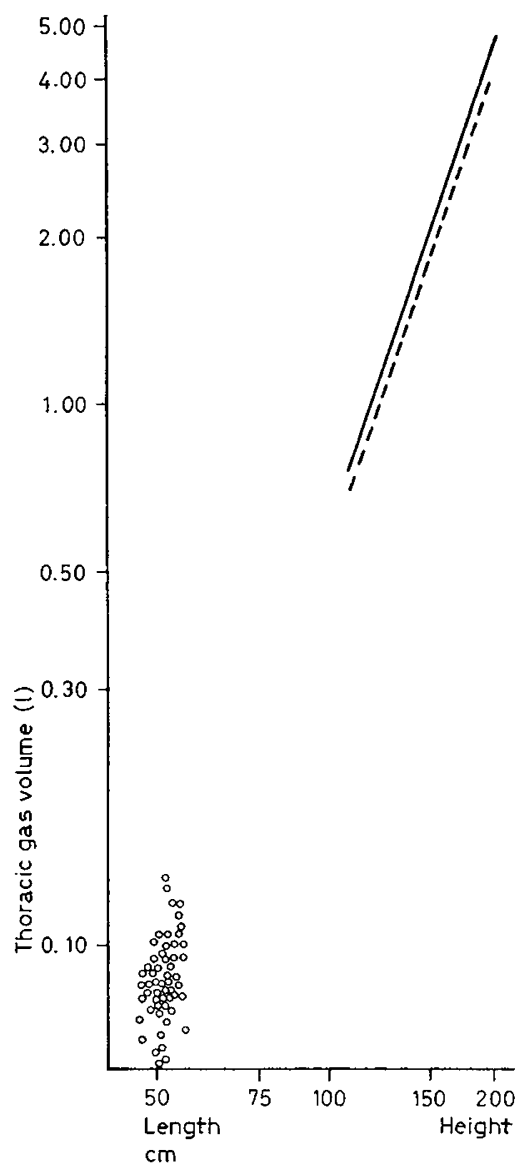

Fig.3. Thoracic gas volume data for 51 newborn infants plotted against length. The solid line indicates the functional residual capacity regression for 106 males studied by helium dilution technique of Cook and Hamann [6]. The dashed line indicates the regression for functional residual capacity by plethysmograph technique for 117 males and females age 6 to 40 years as determined in our laboratory. through the nose. This technique, since it employs a nasal catheter, may stimulate increased secretions and reflex changes in airway resistance and may partially obstruct the nasal airway. These possibilities might explain the higher resistance values obtained by these workers, but are more likely a result of use of a technique that includes tissue resistance. BAGHOFEn and Duc [2] found lung tissue resistance to be $29 \%$ of the total pulmonary resistance in 10 healthy children seven to eleven years of age. If the same relation is true for infants, the difference between our value for airway resistance and those of Cook et al. and SwYER et al. for pulmonary resistance would be readily explained.

The plethysmograph method [7] eliminates the nasal catheter and probably provides a better estimate of the true value for airway resistance, but it might underestimate the value somewhat if, in the presence of small airways, the respiratory rate was too rapid to permit pressure equilibration between mouth and alveoli during lung volume determinations. From analysis of our data, this did not appear likely since rapid respiratory rate did not correlate with low airway resistance or vice versa, and a good straight-line relation was observed.

Several further comments on technical factors are pertinent. Use of an oscilloscope permitted direct visualization of the changing relations of plethysmograph pressure to either airflow or airway pressure. Pressure leaks or abnormal flow patterns were instantly detected. Measurements obtained from recorder tracings are more apt to include faulty samples. Provision for the operator's hand to control the mask during the procedure was also important because it allowed the mandible to be pulled forward gently to maintain a

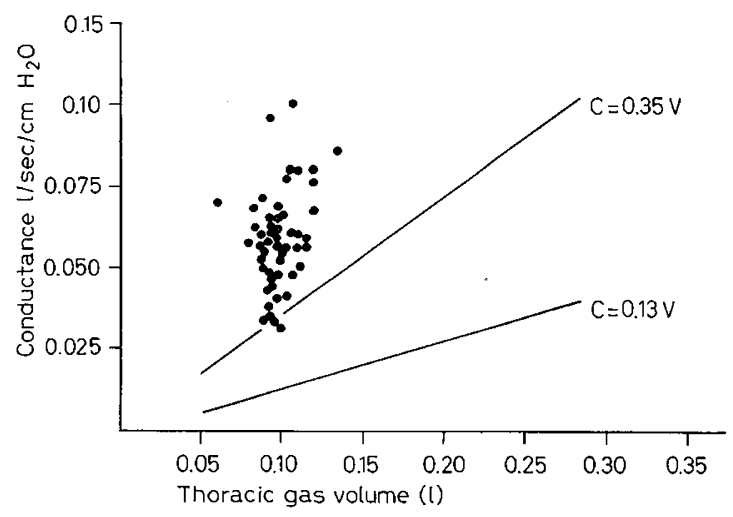

Fig.4. Airway conductance data for 51 newborn infants plotted against lung volume at which it was determined. The regressions indicate the limits of normal projected from the simplified prediction formula of BRIsCOE and DuBors [3]. 
Table I. Individual measurements as well as mean and standard deviations of results

\begin{tabular}{|c|c|c|c|c|c|c|c|c|}
\hline \multirow[t]{2}{*}{ Age } & \multirow[t]{2}{*}{ Weight } & \multirow[t]{2}{*}{ Length } & \multirow{2}{*}{$\begin{array}{c}\text { Functional } \\
\text { residual capacity }\end{array}$} & \multirow{2}{*}{$\begin{array}{l}\text { Airway } \\
\text { resistance }\end{array}$} & \multirow{2}{*}{$\begin{array}{l}\text { Respir- } \\
\text { ation }\end{array}$} & \multirow{2}{*}{$\begin{array}{l}\text { Tidal } \\
\text { volume }\end{array}$} & \multicolumn{2}{|c|}{ Resting peak tidalflow } \\
\hline & & & & & & & $\begin{array}{l}\text { Inspir- } \\
\text { atory }\end{array}$ & $\begin{array}{l}\text { Expir- } \\
\text { atory }\end{array}$ \\
\hline days & $\mathrm{kg}$ & $\mathrm{cm}$ & $\mathrm{ml}$ & $\mathrm{cm} \mathrm{H}_{2} \mathrm{O} / \mathrm{l} / \mathrm{s}$ & $\mathrm{rate} / \mathrm{min}$ & $\mathrm{ml}$ & $1 / \mathrm{s}$ & $\mathrm{I} / \mathrm{s}$ \\
\hline 6 & 3.4 & 53 & $87 \pm 5.9$ & $11.5 \pm 1.1$ & 58 & 33 & 0.12 & 0.11 \\
\hline 2 & 3.0 & 50 & $131 \pm 4.2$ & $12.3 \pm 0.61$ & 60 & 23 & 0.07 & 0.07 \\
\hline 7 & 2.7 & 50 & $74 \pm 5.4$ & $18.8 \pm 1.6$ & 100 & 18 & 0.07 & 0.07 \\
\hline 5 & 3.2 & 50 & $62 \pm 2.7$ & $15.3 \pm 0.79$ & 65 & 25 & 0.08 & 0.06 \\
\hline 1 & 2.6 & 49 & $65 \pm 6.1$ & $16.5 \pm 1.4$ & 71 & 21 & 0.10 & 0.10 \\
\hline 5 & 2.6 & 49 & $66 \pm 10.5$ & $22.8 \pm 3.3$ & 47 & 29 & 0.07 & 0.07 \\
\hline 2 & 3.1 & 50 & $90 \pm 3.5$ & $40.5 \pm 11.2$ & 63 & 25 & 0.08 & 0.08 \\
\hline 3 & 3.1 & 50 & $82 \pm 3.2$ & $16.2 \pm 0.63$ & 78 & 27 & 0.10 & 0.12 \\
\hline 2 & 2.9 & 48 & $81 \pm 3.3$ & $18.3 \pm 0.70$ & 60 & 25 & 0.08 & 0.07 \\
\hline 2 & 2.4 & 47 & $84 \pm 7.3$ & $31.9 \pm 2.5$ & 58 & 23 & 0.07 & 0.05 \\
\hline 2 & 2.9 & 49 & $82 \pm 1.7$ & $17.9 \pm 0.37$ & 71 & 24 & 0.08 & 0.08 \\
\hline 3 & 3.3 & 51 & $91 \pm 3.3$ & $18.2 \pm 0.61$ & 79 & 16 & 0.07 & 0.05 \\
\hline 2 & 3.4 & 51 & $84 \pm 4.4$ & $19.0 \pm 1.0$ & 58 & 21 & 0.10 & 0.07 \\
\hline 2 & 2.4 & 46 & $77 \pm 2.5$ & $22.9 \pm 0.61$ & 83 & 36 & 0.14 & 0.12 \\
\hline 2 & 2.7 & 48 & $79 \pm 2.6$ & $22.5 \pm 0.63$ & 83 & 22 & 0.10 & 0.07 \\
\hline 2 & 2.9 & 48 & $94 \pm 0.98$ & $19.0 \pm 0.22$ & 94 & 25 & 0.12 & 0.10 \\
\hline 2 & 3.1 & 51 & $79 \pm 0.92$ & $22.6 \pm 0.26$ & 54 & 31 & 0.11 & 0.10 \\
\hline 1 & 3.8 & 53 & $82 \pm 2.3$ & $21.8 \pm 0.61$ & 71 & 22 & 0.10 & 0.07 \\
\hline 5 & 2.9 & 50 & $101 \pm 0.9$ & $12.6 \pm 0.70$ & 39 & 30 & 0.08 & 0.05 \\
\hline 5 & 3.0 & 50 & $69 \pm 2.3$ & $19.2 \pm 0.52$ & 40 & 28 & 0.07 & 0.06 \\
\hline 11 & 3.4 & 50 & $97 \pm 5.5$ & $18.7 \pm 0.97$ & 75 & 29 & 0.12 & 0.10 \\
\hline 0.3 & 2.7 & 48 & $105 \pm 5.5$ & $12.8 \pm 0.65$ & 75 & 24 & 0.11 & 0.07 \\
\hline 0.2 & 3.0 & 51 & $102 \pm 4.7$ & $10.3 \pm 0.43$ & 54 & 28 & 0.10 & 0.10 \\
\hline 2 & 2.9 & 49 & $88 \pm 2.2$ & $15.1 \pm 0.31$ & 68 & 20 & 0.04 & 0.06 \\
\hline 2 & 3.1 & 52 & $102 \pm 9.9$ & $18.7 \pm 1.7$ & 88 & 26 & 0.11 & 0.12 \\
\hline 5 & 3.7 & 54 & $79 \pm 9.3$ & $26.8 \pm 2.7$ & 58 & 28 & 0.10 & 0.07 \\
\hline 5 & 3.3 & 50 & $101 \pm 7.1$ & $13.3 \pm 0.83$ & 83 & 22 & 0.07 & 0.08 \\
\hline 3 & 2.5 & 47 & $94 \pm 2.5$ & $17.9 \pm 0.42$ & 79 & 27 & 0.10 & 0.11 \\
\hline 6 & 3.1 & 50 & $80 \pm 4.4$ & $17.1 \pm 0.98$ & 48 & 25 & 0.06 & 0.06 \\
\hline
\end{tabular}

patent pharyngeal airway. Even slight compression of the nose markedly increased airway resistance. This was avoided by using Rendell-Baker masks, which were cut out to allow adequate space for the nose and direct airflow into the adapter tube connecting the mask to the pneumotachometer. Prior to initiating these precautions, we had observed that when we used a remote control device to position and to hold the pneumotachometer and Bennett circular infant face masks, wide variations and erroneously high results were obtained.

Some information about the relation of airway resistance characteristic of the newborn to that of older children and adults is provided from our data. The mean conductance value of $0.052 \mathrm{l} / \mathrm{s} / \mathrm{cm} \mathrm{H}_{2} \mathrm{O}$ lies above the calculated regression of BRISCOE and DuBors [3] (fig.4). An airway resistance value of $40 \mathrm{~cm} \mathrm{H}_{2} \mathrm{O} / 1 / \mathrm{s}$ is required to obtain a conductance value of 0.025 ; however, another variable in measurements of airway resistance would seem to preclude further direct comparison of adults and infants. Adult measurements of airway resistance are usually made at panting flow rates of $0.5 \mathrm{l} / \mathrm{s}$. In this study, the infants achieved flow rates approximating $0.1 \mathrm{l} / \mathrm{s}$. This flow rate is approximately $1 / 5$ that of the older subjects studied. Studies in four normal adults revealed that a four-fold increase in airflow rate from 0.5 to $2.0 \mathrm{l} / \mathrm{s}$ resulted in a two- to three-fold increase in airway resistance during either nose or mouth breathing. We have also observed considerable increases in airway resistance in newborn infants during involuntary deep breaths, when resting flow rates doubled or tripled. Since resistance to 
Table $I$. Individual measurements as well as mean and standard deviations of results

\begin{tabular}{|c|c|c|c|c|c|c|c|c|}
\hline \multirow[t]{2}{*}{ Age } & \multirow[t]{2}{*}{ Weight } & \multirow[t]{2}{*}{ Length } & \multirow{2}{*}{$\begin{array}{l}\text { Functional } \\
\text { residual capacity }\end{array}$} & \multirow{2}{*}{$\begin{array}{l}\text { Airway } \\
\text { resistance }\end{array}$} & \multirow{2}{*}{$\begin{array}{l}\text { Respir- } \\
\text { ation }\end{array}$} & \multirow{2}{*}{$\begin{array}{l}\text { Tidal } \\
\text { volume }\end{array}$} & \multicolumn{2}{|c|}{ Resting peak tidalfow } \\
\hline & & & & & & & $\begin{array}{l}\text { Inspir- } \\
\text { atory }\end{array}$ & $\begin{array}{l}\text { Expir- } \\
\text { atory }\end{array}$ \\
\hline days & $\mathrm{kg}$ & $\mathrm{cm}$ & $\mathrm{ml}$ & $\mathrm{cm} \mathrm{H}_{2} \mathrm{O} / \mathrm{l} / \mathrm{s}$ & $\mathrm{rate} / \mathrm{min}$ & $\mathrm{ml}$ & $1 / \mathrm{s}$ & $\mathrm{I} / \mathrm{s}$ \\
\hline 3 & 3.3 & 51 & $111 \pm 10.8$ & $17.2 \pm 1.2$ & 21 & 21 & 0.08 & 0.08 \\
\hline 3 & 2.8 & 47 & $84 \pm 1.8$ & $15.4 \pm 2.1$ & 83 & 30 & 0.12 & 0.14 \\
\hline 1 & 3.2 & 54 & $90 \pm 7.7$ & $27.8 \pm 1.6$ & 60 & 33 & 0.07 & 0.08 \\
\hline 3 & 3.0 & 50 & $88 \pm 2.2$ & $19.7 \pm 0.45$ & 100 & 20 & 0.10 & 0.12 \\
\hline 5 & 3.4 & 53 & $104 \pm 9.6$ & $16.4 \pm 1.4$ & 75 & 26 & 0.08 & 0.08 \\
\hline 5 & 3.6 & 54 & $103 \pm 2.3$ & $21.8 \pm 1.3$ & 54 & 24 & 0.07 & 0.10 \\
\hline 1 & 3.5 & 53 & $90 \pm 6.7$ & $28.5 \pm 4.4$ & 58 & 24 & 0.08 & 0.06 \\
\hline 4 & 2.7 & 50 & $66 \pm 3.4$ & $18.1 \pm 2.0$ & & & & \\
\hline 3 & 3.5 & 49 & $93 \pm 5.6$ & $17.8 \pm 2.6$ & & & & \\
\hline 3 & 2.6 & 49 & $77 \pm 1.7$ & $16.9 \pm 0.27$ & & & & \\
\hline 6 & 3.7 & 53 & $112 \pm 4.7$ & $13.7 \pm 1.8$ & & & & \\
\hline 10 & 2.8 & 47 & $89 \pm 1.8$ & $18.8 \pm 0.44$ & & & & \\
\hline 1 & 2.4 & 46 & $87 \pm 13.2$ & $15.9 \pm 2.3$ & & & & \\
\hline 2 & 2.2 & 46 & $71 \pm 8.7$ & $22.9 \pm 8.5$ & & & & \\
\hline 1 & 3.0 & 47 & $92 \pm 24.1$ & $19.6 \pm 4.47$ & & & & \\
\hline 1 & 3.1 & 49 & $100 \pm 14.3$ & $13.2 \pm 2.6$ & & & & \\
\hline 0.1 & 2.8 & 50 & $87 \pm 5.9$ & $29.1 \pm 5.1$ & & & & \\
\hline 3 & 3.0 & 50 & $126 \pm 28.9$ & $16.7 \pm 4.4$ & & & & \\
\hline 1 & 2.9 & 50 & $108 \pm 16.9$ & $18.3 \pm 3.3$ & & & & \\
\hline 3 & 2.9 & 49 & $77 \pm 10.1$ & $26.2 \pm 6.4$ & & & & \\
\hline 0.3 & 3.8 & 52 & $127 \pm 16.5$ & $11.4 \pm 3.6$ & & & & \\
\hline 0.5 & 4.1 & 53 & $106 \pm 11.6$ & $20.8 \pm 2.7$ & & & & \\
\hline 51 subjects & & & & & 36 subjec & & & \\
\hline $3.2 \pm 2.0$ & $3.0 \pm 0.5$ & $49.9 \pm 2.0$ & $89.9 \pm 15.5$ & $19.2 \pm 5.6$ & $67 \pm 17$ & $25 \pm 4.3$ & $0.09 \pm 0.0$ & $.08 \pm 0.02$ \\
\hline
\end{tabular}

Airway resistance and thoracic gas volume at functional residual capacity in 51 newborn infants. The resting respiratory rate, tidal volume, and airflow rates were determined before or after the airway resistance and lung volume measurements and are not basal. The flow rates during determination of airway resistance approximated $0.1 \mathrm{l} / \mathrm{s}$.

airflow is a function of the diameters and lengths of the tubes involved and of the rate of gas flow, airway resistance cannot be related to a single parameter of lung size, such as lung volume, unless all measurements are made at similar flow rates. Considering these differences in flow rates, one would expect the results obtained in these infants to deviate from the calculated regressions obtained using the data from older subjects in the direction actually observed. These results point to the need for age-specific normal values for airway resistance throughout infancy and early childhood.

POLGAR and Kong [12] calculated a value of $12.1 \pm$ $5.5 \mathrm{~cm} \mathrm{H}_{2} \mathrm{O} / \mathrm{l} / \mathrm{s}$ for nasal resistance in five newborn infants. Subtraction of this value from that of the infants in the present study, during nasal breathing, gives a calculated value of $7.1 \mathrm{~cm} \mathrm{H}_{2} \mathrm{O} / \mathrm{l} / \mathrm{s}$ for oral air- way resistance (conductance $=0.14$ ). These results suggest that nasal airway resistance in the newborn infant constitutes a major part of total airway resistance.

\section{Summary}

Using the total body plethysmograph method [7], fifty-one newborn infants were studied to determine thoracic gas volume at functional capacity and airway resistance at this volume. The volume of functional residual capacity was $89.9 \pm 15.5 \mathrm{ml}(29 \pm 6 \mathrm{ml} / \mathrm{kg})$ for these infants whose mean length was $49 \mathrm{~cm}$. The mean value for airway resistance was $19.2 \mathrm{~cm} \mathrm{H}_{2} \mathrm{O} / \mathrm{l} / \mathrm{s}$. The mean value for conductance (reciprocal of airway resistance) of $0.052 \mathrm{l} / \mathrm{s} / \mathrm{cm} \mathrm{H}_{2} \mathrm{O}$ fell outside the pro- 
jected regressions determined by BRISCOE and DuBors [3]. Airway resistance was determined in these newborns when the airflow rate was $0.1 \mathrm{l} / \mathrm{s}$, a value considerably less than that of older subjects who have been studied. Inability to measure airway resistance at similar flow rates limits direct comparisons of airway resistance in infants and older children. Age-specific normal values are needed throughout infancy and early childhood.

\section{References and $\mathcal{N}$ otes}

1. Auld, P.A.M.; Nelson, N.M.; Gherry, R.B.; Rudolph, A.J. and Smith, C.A.: Measurement of thoracic gas volume in the newborn infant. $J$. clin. Invest. 42: 476 (1963).

2. BAchofen, H. and Duc, G.: Lung tissue resistance in healthy children. Pediat. Res. 2: 119 (1968).

3. Briscoe, W. A. and DuBors, A. B. : The relationship between airway resistance, airway conductance and lung volume in subjects of different age and body size. J. clin. Invest. 37: 1279 (1958).

4. Chu, J. S.; Dawson, P.; Klaus, M. and Sweet, A.Y.: Lung compliance and lung volume measured concurrently in normal full-term and premature infants. Pediatrics 34: 525 (1964).

5. Gook, G.D.; Sutherland, J.M.; Segal, S.; Gherry, R.B.; Mead, J.: Mallroy, M.B. and Smith, C.A.: Studies of respiratory physiology in the newborn infant. III. Measurements of mechanics of respiration. J. clin. Invest. 37: 440 (1957).

6. Cook, C.D. and Hamann, J.F.: Relation of lung volumes to height in healthy persons between the ages of 5 and 38 years. J. Pediat. 59: 710 (1961).

7. DuBors, A.B.; Botelho, S.Y. and Comroe, J.H., Jr.: A new method for measuring airway resistance in man using a body plethysmograph: values in normal subjects and in patients with respiratory disease. J. clin. Invest. 35: 327 (1956).

8. Klaus, M.; Tooley, W.H.; Weaver, K.H. and Cilements, J.A.: Lung volume in the newborn infant. Pediatrics 30: 111 (1962).

9. MEAD, J.: Mechanical properties of lungs. Physiol. Rev. 41: 281 (1961).

10. Nelson, N.M.; Prod'hom, S.L.; Cherry, R.B.; Lipsitz, P.J. and Sмith, G. A.: Pulmonary function in the newborn infant. V. Trapped gas in the normal infants lung. J. clin. Invest. 42: 1850 (1963).

11. Polgar, G.: Airway resistance in the newborn infant. J. Pediat. 59: 915 (1961).

12. Polgar, G. and Kong, G.P.: The nasal resistance of newborn infants. J. Pediat. 67: 557 (1965).

13. SwYer, P.R.; Reiman, R.C. and Wright, J.J.: Ventilation and ventilatory mechanics in the newborn. J. Pediat. 56: 612 (1960).

14. MacDonald House Nurseries, University Hospitals of Cleveland, Ohio.

15. The authors wish to acknowledge the assistance of Dr. C.T.Gillespie and Dr. P.E.Vanik; Marvin Lough, ARIT, Carl Frank, Jim Wheelis, and Mrs. Lee Johnson, technicians; and Ruth Fagan and Mary Ann Mate, secretaries, in the completion of this project.

16. This study was supported by Grants 06748 and 08305 from the National Institute for Arthritis and Metabolic Diseases, Grant FR-87 from the National Institutes of Health, Children's Clinical Research Center, and by the Cleveland Chapter of the National Cystic Fibrosis Research Foundation.

17. Requests for reprints should be addressed to: CARL F. Doershuk, M.D., Department of Pediatrics, Case Western Reserve University School of Medicine, 2103 Adelbert Road, Cleveland, Ohio 44106 (USA). 